\title{
Trial of probiotics to prevent the vertebral column compression syndrome in rainbow trout (Oncorhynchus mykiss Walbaum)
}

\author{
Joël Aubin ${ }^{1 *}$, François-Joël Gatesoupe ${ }^{2}$, Laurent Labbé ${ }^{1}$ and Luc Lebrun ${ }^{1}$ \\ ${ }^{1}$ Station Expea rimentale Mixte Ifremer INRA (SEMII), Barrage du Drennec, Sizun, France \\ ${ }^{2}$ Unitea Mixte de Recherche en Nutrition, Aquaculture et Gea nomique, INRA Ifremer, Centre de Brest, Brest, \\ France \\ *: Corresponding author : JAubin, Unitea Mixte de Recherche INRA-Agrocampus Sol Agronomie et \\ Spatialisation,65 rue de St Brieuc, CS 84215, 35042 Rennes cedex, France. E-mail: Joel.Aubin@rennes.inra.fr
}

\begin{abstract}
Two probiotics were tested as alternative treatment to limit the prevalence of the vertebral column compression syndrome (VCCS) in rainbow trout, compared with a preventive treatment with florfenicol. Either the antibiotic, or a lactic acid bacterium, Pediococcus acidilactici, or a yeast, Saccharomyces cerevisiae var. boulardii, was introduced into experimental diets, which were compared with the control diet without supplementation. The antibiotic caused some mortality during the first week after treatment, likely because of the toxicity of the compound. However, this antibiotic treatment limited the occurrence of VCCS to $3 \%$, vs. $13 \%$ of fish affected in the control group. Pediococcus acidilactici provided the same level of protection as the antibiotic, but on condition that the treatment was applied during the 5 months of the experiment, without any adverse effect on survival. A treatment with $P$. acidilactici only during the first 20 days of feeding was not sufficient to limit VCCS, nor was the treatment with the yeast sufficient. These results were discussed while comparing the microbiota associated with the intestine. The experiment reinforced the hypothesis that pathogenic bacteria are involved in VCCS. The long-term dietary supplementation with P. acidilactici seemed promising as a preventive treatment against the syndrome, but large-scale investigation in fish farms will be necessary to confirm its prophylactic relevance.
\end{abstract}

Keywords: spinal deformities, yeast, lactic acid bacterium, antibiotic, Pseudomonas, Debaryomyces hansenii, Carnobacterium 


\title{
Trial of probiotics to prevent the vertebral column compression syndrome in rainbow trout (Oncorhynchus mykiss Walbaum).
}

\author{
Joël Aubin ${ }^{1 *}$, François-Joël Gatesoupe ${ }^{2}$, Laurent Labbé ${ }^{1}$, Luc Lebrun ${ }^{1}$ \\ 1: Station Expérimentale Mixte Ifremer INRA (SEMII), Barrage du Drennec, BP 17, 29450 Sizun, France \\ 2: Unité Mixte de Recherche en Nutrition, Aquaculture et Génomique, INRA Ifremer, Centre de Brest, BP 70, \\ 29280 Brest, France
}

Correspondence (*present address): J. Aubin, Unité Mixte de Recherche INRA-Agrocampus Sol Agronomie et Spatialisation, 65 rue de St Brieuc, CS 84215, 35042 Rennes cedex, France. E-mail: Joel.Aubin@rennes.inra.fr

\begin{abstract}
Two probiotics were tested as alternative treatment to limit the prevalence of the Vertebral Column Compression Syndrome (VCCS) in rainbow trout, compared with a preventive treatment with florfenicol. Either the antibiotic, or a lactic acid bacterium, Pediococcus acidilactici, or a yeast, Saccharomyces cerevisiae var. boulardii, was introduced into experimental diets, which were compared to the control diet without supplementation. The antibiotic caused some mortality during the first weeks after treatment, likely due to the toxicity of the compound. However, this antibiotic treatment limited the occurrence of VCCS to $3 \%$, vs. $13 \%$ of fish affected in the control group. P. acidilactici provided the same level of protection as the antibiotic, but on condition that the treatment was applied during the five months of the experiment, without any adverse effect on survival. A treatment with $P$. acidilactici only during the first 20 days of feeding was not sufficient to limit VCCS, nor was sufficient the treatment with the yeast. These results were discussed while comparing the microbiota associated with the intestine. The experiment reinforced the hypothesis that pathogenic bacteria are involved in VCCS. The long-term dietary supplementation with $P$. acidilactici seemed promising as a preventive treatment against the syndrome, but large scale investigation in fish farms will be necessary to confirm its prophylactic relevance .
\end{abstract}

Keywords: spinal deformities, yeast, lactic acid bacterium, antibiotic, Pseudomonas, Debaryomyces hansenii, Carnobacterium.

\section{Introduction}

There have been many reports of spinal deformities in salmonid production. This phenomenon has occurred with a high prevalence in European fish farms, particularly in Norway (Poppe 2000). It induces economic loss for fish farmers, who have to discard great numbers of fish unfit for sale.

The Vertebral Column Compression Syndrome (VCCS) has been described as a frequent spinal deformity. This syndrome is characterised by width reduction of the vertebrae, associated with the fusion of some of them. Fish may be shortened longitudinally, while displaying various shapes, depending on the number and location of the fused vertebrae. Two main shapes have been usually described (1) "cyprinid conformation" due to the fusion of antero-truncal vertebrae (Poynton 1987), and (2) "short tail" due to trunco-caudal fused 
vertebrae. The syndrome is not limited to fish farming, since it affected around $3 \%$ of salmonids caught in the wild (Charles \& Fisk 1966).

A wide range of aetiologies have been proposed to explain the vertebral compression, which may be caused by nutritional factors (Madsen \& Dalsgaard 1999), genetic factors (Vagsholm \& Djupvik 1998), triploidy (Sadler, Pankhurst \& King 2001), environmental factors (Vagsholm \& Djupvik 1998; Gjerde B., Pante J.R. \& Baeverfjord G. 2000), toxicant exposure (Madsen, Arnbjerg \& Dalsgaard 2000), and infection (Margolis, Kent \& Bustos 1996; Madsen \& Dalsgaard 1999; Kvellestad, Hoie, Thorud \& Lyngoy 2000).

Histological examination on Salmo salar suggested an infectious aetiology of VCCS (Kvellestad et al. 2000). Madsen \& Dalsgaard (1999) showed that the addition of glucan in the diet of rainbow trout decreased the incidence of the syndrome, while a disease outbreak caused by Flavobacterium psychrophilum was observed during the experiment. These authors concluded to a multi-factorial cause involving infection, immunity, and heredity. Madsen, Arnbjerg \& Dalsgaard (2001) confirmed that $F$. psychrophilum could cause spinal deformities after experimental infection at the fry stage, due to numerous compressed or fused vertebrae, and collapsed intervetebral spaces. The infection has been described as the "coldwater disease", and oxytetracycline was recommended as antibiotic treatment (Groff \& LaPatra 2000). Madsen et al. (2001) showed that a short-term treatment with oxytetracycline did not affect the rate of spinal deformities, whereas Toften \& Jobling (1996) observed spinal fractures due to a long-term treatment.

However, antibiotics should not be used for prophylaxis because of the risk to spread antibacterial resistance (Miranda \& Zemelman 2002). Among the alternative solutions, some probiotic treatments may offer the advantage to combine their direct antagonism to pathogens with the concomitant immunostimulation of the host. Lactic acid bacteria have been documented in fish from this regard (Villamil, Tafalla, Figueras \& Novoa 2002; Nikoskelainen, Ouwehand, Bylund, Salminen \& Lilius 2003). Yeast may also stimulate immunity in fish (Siwicki, Anderson \& Rumsey 1994; Duncan \& Klesius 1996; Ortuño, Cuesta, Rodriguez, Esteban \& Meseguer 2002; Esteban, Rodriguez \& Meseguer 2004).

The present experiment was based on the findings of Madsen \& al. (2001), and designed to compare the effects on conformation of fish short-term treated at the fry stage with either antibiotic, lactic acid bacterium, or yeast. The two probiotics were also tested in a long-term treatment.

\section{Materials and Methods}

Fish and rearing conditions

The experiment was conducted in SEMII experimental fish farm at Sizun (France). Rainbow trout broodstock selected to spawn in autumn ("Autumnal Strain") was chosen because of its proclivity to develop VCCS. The spawn was obtained by pooling the fertilisation products from 31 females and 66 males. At the eyed stage, 18 lots of 500 eggs were dispatched into incubators. The survival rate from fertilisation to start swimming was ca. $90 \%$.

The fish were reared in $200 \mathrm{~L}$ fibreglass tanks supplied with spring water at $11.0 \pm 0.5^{\circ} \mathrm{C}$, and they were fed ad libitum.

Growth was monitored by weighing fish every three weeks. The dead were counted three times a week.

Diets and experimental groups 
The control diet was Ecoweaner ${ }^{\circledR}$, then Ecostart ${ }^{\circledR}$, depending on the size of the fingerlings (Biomar S.A., Nersac, France). The experimental diets with probiotics were prepared by the manufacturer. To this end, dry pellets of the control diet (Ecoweaner ${ }^{\circledR}$ then Ecostart ${ }^{\circledR}$ ) were coated by spraying a suspension of the probiotic in fish oil. The probiotics were Pediococcus acidilactici MA $185 \mathrm{M}$ (Institut Pasteur) and Saccharomyces cerevisiae var. boulardii CNCM I-1079 (Institut Pasteur). After coating, the mean concentration of the probiotics in the diet was $(1.5 \pm 0.4) \times 10^{6}$ and $(4.0 \pm 0.1) \times 10^{6} \mathrm{CFU} \mathrm{g}^{-1}$ of pellets, for the lactic acid bacterium and for the yeast, respectively. Another experimental diet was prepared in the laboratory by spraying a suspension of florfenicol $\left(\right.$ Nuflor $^{\mathbb{R}}$ ) on control diet pellets (Ecoweaner ${ }^{\mathbb{R}}$ ), to obtain a dose of $18 \mathrm{mg} \mathrm{kg}^{-1}$ of active compound in the diet prepared for the group treated with the antibiotic.

The experiment lasted five months from first feeding onwards. Six groups were allocated in triplicates. Group C was fed for five months with the control diet. Group A was fed with the diet supplemented with antibiotic for the first ten days, then with the control diet afterwards. Groups B1 and L1 were fed for the first 20 days with the diets supplemented with $P$. acidilactici and $S$. cerevisiae, respectively, then with the control diet afterwards. Groups B5 and L5 were fed for five months with the diets supplemented with the bacterium and the yeast, respectively.

\section{Microbiological examination}

Three fish were sampled in each tank at 20 day post start feeding (dpsf), after $20 \mathrm{~h}$ of starvation. The fingerlings were euthanized with an overdose of 2-phenoxyethanol, and the corporal surface was disinfected with ethanol $\left(70^{\circ} \mathrm{B}\right)$. In sterile conditions, the hindgut was dissected, weighed and crushed in a glass homogenizer with $4.5 \mathrm{ml}$ of $1 / 4$-strength Ringer's solution, prepared with Ringer's tablets (Merck 15525). Appropriate tenfold dilutions made with the same solution were spread on Petrifilm (Aerobic Count Plates, 3M Microbiology products), and incubated at $11^{\circ} \mathrm{C}$. MRS agar (AES Laboratoire) was used to count $P$. acidilactici (incubation at $45^{\circ} \mathrm{C}$ for $48 \mathrm{~h}$ in an anaerobic jar). The yeast were counted on Sabouraud agar (AES Laboratoire) supplemented with antibiotics (chloramphenicol, $1 \mathrm{mg} \mathrm{L}^{-1}$; polymixin B sulfate, $0.8 \mathrm{mg} \mathrm{L}^{-1}$; amoxicillin, $1.25 \mathrm{mg} \mathrm{L}^{-1}$ ) after $48 \mathrm{~h}$ of incubation at $30^{\circ} \mathrm{C}$. The probiotic yeast appeared as large white colonies within $24-48 \mathrm{~h}$. Afterwards, the plates were stored at room temperature, and autochthonous yeast were recovered by one week. At 30 dpfs, ten days after the end of the probiotic treatments in groups B1 and L1, three fingerlings were sampled in each tank of these groups to count $P$. acidilactici and the probiotic yeast, as described above. By the end of the experiment after 5 months of feeding, three fish were again sampled in every tank of groups C, B5, and L5 for microbial counts on Petrifilm, MRS agar, and Sabouraud agar supplemented with antibiotics.

Eight colonies were randomly isolated from each individual Petrifilm and Sabouraud plate for phenotypic characterisation of bacteria and yeast, respectively. The Petrifilm and Sabouraud isolates were cultivated on Plate Count Agar (PCA, AES Laboratoire) and Sabouraud agar, respectively. The Phenotypes of the isolates of bacteria and yeast were characterised with API 20 E, and API 20 Aux strips, respectively, according to the manufacturer's instructions (BioMérieux). The phenotypic profiles were compared and classified with the Wagner parsimony method, by using Mix of Phylip (Felsenstein 1996).

The isolates representative of the different phenotypic profiles were cultured again for DNA extraction. Bacterial DNA fragments corresponding to the 16S rRNA gene were amplified by PCR. The isolates were clustered according to their genotypic similarity, characterised by Amplified Ribosomal DNA-Restriction Analysis (ARDRA) of the PCR products by using 
Hae III and Cfo I (Gatesoupe 2002). One isolate per each dominant cluster was selected for sequencing the 16S rRNA gene (partial sequences of 466-854 bp from primer SA-dir 5'-agagtttgatcatggctcag-3'). The phylogenic position of the cluster was then searched with BLAST (NCBI). Yeast DNA was extracted with glass bead (Hoffman \& Winston 1987), then PCR was performed with primers ITS1 and ITS4 corresponding to the region of 5.8S and 28S rRNA genes (Petersen, Moller \& Jespersen 2001). The yeast PCR products were characterised by ARDRA as described above, and those corresponding to the dominant strains were sequenced (ITS 1, 5.8S rRNA gene, ITS 2, and partial sequence of 28S rRNA gene, 478-591 bp, from primer ITS1 5'-tccgtaggtgaacctgcgg-3').

\section{Radiography}

By the end of the experiment, 50 fish were sampled from each tank to measure individual body weight and fork length, before examining vertebral conformation. The samples were Xray radiogaphed on medical Phasix 65 (CGR Koch \& Sterzel), by using Kodak X-OMAT MA films. The fish with at least two fused vertebrae were counted as affected by VCCS. According to Kacem, Meunier, Aubin \& Haffray (2004), who defined anatomic regions of the vertebral column in rainbow trout after the length/height ratio of the vertebrae, we considered four anatomic regions in the spinal axis, viz cranial, trunco-cranial, trunco-caudal, and caudal regions, corresponding to vertebrae nos. 1-8, 9-30, 31-51, and 52-60, respectively.

For statistical analysis, the percentages of survival and vertebral anomalies were arcsine square root transformed, whereas the bacterial counts were log transformed. ANOVA was used, then Duncan test was performed to discriminate the homogeneous groups by using Statistica V. 5.1 (StatSoft. Inc.).

\section{Results}

Growth was good in every group, and the mean weights and lengths were not significantly different at the end of the experiment (Table 1). Mortality occurred mainly during the first four weeks, and it was mainly due to the lack of start-feeding in some fry. By the end of the experiment, the cumulative mortality was around $10 \%$, except for the group treated with the antibiotic (19\%). This difference was significant.

The proportion of fish with VCCS ranged from 0 to $18 \%$ among the groups, with a significant difference observed between the control C (13\%) and groups A and B5 (3 and $4 \%$, with $P=$ 0.004 and 0.026 for groups A and B5, respectively; Fig. 1). There was also a significant difference between groups A and B1 $(P=0.006)$, while groups L1 and L5 were not significantly different from the others.

Most fused or compressed vertebrae were located in the trunco-caudal region of the spinal axis (Fig.2), whereas none of them were observed in the cranial region (Table 2). The severity of the syndrome was variable, since the number of abnormal vertebrae counted in one malformed fish varied from 2 to 32. The low occurrence of VCCS did not allow testing the effect of diet on the number of abnormal vertebrae, and few individuals grievously affected were retrieved among the experimental groups, independently of the diet.

At 20 dpsf, the bacterial counts in the intestine were ca. $10^{5}-10^{6} \mathrm{CFU} \mathrm{g}{ }^{-1}$ (Table 3). The difference was not significant, due to the high variability of the counts in group A, 10 days after stopping the antibiotic treatment. However, there was a trend to observe the lowest counts in groups L and B. At this date, the bacteria associated with the control group $\mathrm{C}$ were 
more diverse than in the others groups, where Pseudomonas sp. was largely dominant (54$62 \%$ of the isolates, vs. $19 \%$ in group C; Table 4). This dominant strain had $100 \%$ similarity in a 809 bp DNA fragment, corresponding to the 16S rRNA gene of Pseudomonas sp. E2.2 (Ceremonie, Buret, Simonet \& Vogel 2004). Enterobacteriaceae were dominant in Group C with $43 \%$ of the isolates, but they corresponded to diverse species, mainly Ewingella americana, and Enterobacter sp. Between 4-8\% of Aeromonas sp. was found in all the groups, and the strain was closely related to A. sobria ATCC 43979T (Ruimy, Breittmayer, Elbaze, Lafay, Boussemart, Gauthier \& Christen 1994). A small proportion of Gram positive isolates were also retrieved in the groups fed with the probiotics, Arthrobacter sp. in both groups, and Carnobacterium sp. in Group B.

Autochthonous yeast were present at a relatively high level, but the means of the groups were not significantly different $\left(10^{3}-10^{5} \mathrm{CFU} \mathrm{\textrm {g } ^ { - 1 }}\right)$, due to the high variability observed in Group $\mathrm{L}$ (Table 3). All the isolates of Groups C, B and L corresponded to Debaryomyces hansenii YB3A3 (sequence deposited as AJ849473), a strain closely related to D. hansenii var. fabryi CBS789 (Petersen et al. 2001). The strain was also dominant in Group A $(69 \%$ of the isolates), but two other yeast were isolated: Trichosporon sp. YL2C3 (23\% of the isolates, sequence deposited as AJ849472), and Rhodotorula mucilaginosa (8\% of the isolates, accession number of an homologous fragment: AF444635, position of the first and the last nucleotides corresponding to the fragment in the referenced sequence: 51-617).

At $20 \mathrm{dpsf}$, the probiotic yeast was associated to the intestine of fish from Groups $\mathrm{L}$ at a level similar to those observed with autochthonous yeast $\left(10^{4} \mathrm{CFU} \mathrm{\textrm {g } ^ { - 1 }}\right.$, Table 3$)$, while the amount of the probiotic bacterium was low in Groups B $\left(10^{2} \mathrm{CFU} \mathrm{g} \mathrm{g}^{-1}\right)$. The probiotic strains were not detected in Groups L1 and B1 at 30 dpfs, ten days after stopping the experimental treatment.

After 5 months of feeding, a significant difference in bacterial counts was observed between Groups $\mathrm{C}$ and B5 $\left(10^{6}\right.$ and $10^{4} \mathrm{CFU} \mathrm{g}^{-1}$, respectively; Table 5). The dominant strains were Carnobacterium sp., closely related to C. maltaromaticum (Rudi, Maugesten, Hannevik \& Nissen 2004; Table 6). The strain was especially dominant in Group L5 (90\% of the isolates), whereas Aeromonas sp. and Enterobacteriaceae were also found in the other groups. Autochthonous yeast were also isolated from fish fed with the probiotics, but at a low level ( $\leq$

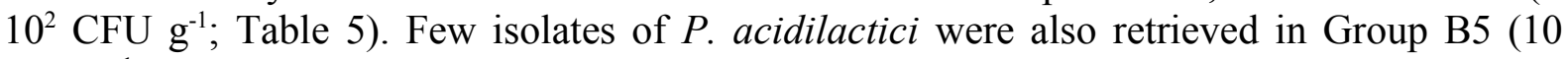
CFU g ${ }^{-1}$ ), while the probiotic yeast was not detected in Group L5, after $20 \mathrm{~h}$ of starvation.

\section{Discussion}

The spontaneous occurrence of VCCS may explain at least partly the high variability observed in the rates of malformation. In the control group, this rate was higher than those commonly reported (e.g. Vagsholm \& Djupvik 1998), unlike in the group treated with antibiotics, or in the group fed for 5 months with $P$. acidilactici. These last two treatments significantly decreased the prevalence of VCCS to a level similar to that observed in wild salmons (Charles $\&$ Fisk 1966), but they could not cope with every cause of spinal deformities, for instance those stemming from early organogenesis.

The swimming type of salmonids is sub-carangiform. It is characterised by an undulation of the upper half part of the body and a high torsion of the medium region of the spinal axis (Ramzu \& Meunier 1999). In our experiment, the preferential location of the deformities was in the trunco-caudal region. This area is specifically involved in trout swimming, and that may reveal a specific weakness of the bone tissue of the vertebrae. Such weakness was evoked by Kacem et al. (2004), who examined the spinal axis of portion sized rainbow trout in the same fish farm. The authors described wide erosive lacunae associated with low osseous compacity in the normal and compressed vertebrae. The cause of this defect of bone tissue has not been 
cleared up, but some perturbation in the phospho-calcic balance have been suspected, possibly due to the high growth rate of farmed trout.

However, the hypothesis that some pathogenic bacteria would be involved in VCCS seems reinforced with the efficiency of the antibiotic treatment in our experiment.

$F$. psychrophilum has been frequently reported in French fish farms, and it should be further investigated whether VCCS may be assimilated with the coldwater disease (Groff \& LaPatra 2000). Most abnormal vertebrae were located in the trunco-caudal region in our experiment, whereas the cranial and caudal regions were mainly affected in case of experimental infection with F. psychrophilum (Madsen et al. 2001). The characteristic external symptoms and lesions of the coldwater disease were not observed during the experiment. Moreover, the only mortality crisis was noted during the first four weeks of feeding in the group treated with the antibiotic, likely due to the toxicity of the compound. Though the incident was limited, this increased mortality may indicate an additional disadvantage of the antibiotic over the probiotic, besides the risk of resistance spread.

A short treatment of 20 days with the probiotic was not long enough to be effective, while the 10 days of treatment with the antibiotic were sufficient. This may suggest two different mechanisms of action for the antibiotic and the probiotic. During the first 10 days of feeding, the digestive tract is suddenly confronted with the water flow carrying microbes, while the intestinal barrier may be still frail (Suzuki 2001). The early antibiotic treatment might have hindered the infection by the putative pathogen during this critical period. Some strains of $P$. acidilactici are known to produce bacteriocins (Bhunia, Johnson, Ray \& Belden 1990; Mora, Parini, Fortina \& Manachini 2002). The significant limitation of bacterial load after 5 months of feeding with the probiotic indicated that this strain might have bacteriostatic properties, though the effect was not significant at $20 \mathrm{dpfs}$. It is possible that the antagonism of the probiotic against the pathogen was sufficient to hinder the disease as long as the probiotic was present, but insufficient to eradicate the pathogen. That might account for the treatment duration necessary with the probiotic, which was longer than the duration required with the antibiotic. Further investigation is required to determine a minimum duration for VCCS prevention by the probiotic. It would be interesting to study the ontogeny and the evolution of the disease, but the early detection of vertebral deformities and the measurement of ossification kinetic in fish fry require the development of other investigation techniques..

Other mechanisms of action may be hypothesised for the probiotic, like immuno-modulation. To our knowledge, there is one report about lobster immunisation with Pediococcus homari (Schapiro, Mathewson, Steenbergen, Kellogg, Ingram, Nierengarten \& Rabin 1974), but any effect on the immune system has not been reported with $P$. acidilactici (Bhunia et al. 1990; Villamil et al. 2002).

The probiotic strain of $P$. acidilactici was retrieved at a low level in the intestine after $20 \mathrm{~h}$ of starvation $\left(\leq 10^{2} \mathrm{CFU} \mathrm{g}^{-1}\right)$. Lésel, Fauconneau \& Alzieu (1986) showed that most transiting bacteria were defecated $10 \mathrm{~h}$ after ingestion by rainbow trout at $13^{\circ} \mathrm{C}$. The probiotic was thus transient, without noticeable mucosal association. By contrast, the probiotic yeast was still present at $10^{4} \mathrm{CFU} \mathrm{g}^{-1}$ in the intestine after $20 \mathrm{~h}$ of starvation at $20 \mathrm{dpfs}$. The yeast was thus associated with mucosa at the fry stage, at least for several hours, but it was not any longer detected 10 days after stopping the treatment. The probiotic yeast was not found at all after five months.

Autochthonous yeast were also retrieved in high numbers at $20 \mathrm{dpfs}$. The presence of yeast in salmonids intestinal microbiota has been frequently reported, but their proportion of the total microbial counts was very variable, up to $59 \%$ of the isolates in Oncorhynchus sp. (Yoshimizu, Kimura \& Sakai 1976, reported by Ringø, Strøm \& Tabachek 1995). In rainbow trout intestine, Andlid, Juárez \& Gustafsson (1995) found ca. $10^{2}-10^{4} \mathrm{CFU} \mathrm{g}{ }^{-1}$, most of the isolates being classified as $S$. cerevisiae and $D$. hansenii, while Rhodotorula spp. were also subdominant. Our findings seem in agreement with these data, but $S$. cerevisiae was not 
retrieved in the autochthonous flora. Moreover, Andlid et al. (1995) studied 10-15g juveniles of rainbow trout, which corresponded to the size of our fish by the end of the experiment, when the amount of autochthonous yeast was low. The colonisation potential of the strains isolated by Andlid et al. (1995) seems therefore more marked than that of our strain of $D$. hansenii. The same authors noted that their strain of $D$. hansenii was a better coloniser than their strain of $S$. cerevisiae, after feeding the trout for two months with both strains in combination. Consequently, the natural occurrence of $D$. hansenii at the fry stage may explain the weak effect of the probiotic $S$. cerevisiae. This treatment may have even conflicted with the natural population settlement, in view of the high variability observed in the counts of autochthonous yeast in the group fed with the probiotic yeast at $20 \mathrm{dpfs}$. D. hansenii may stimulate the mucosal metabolism in rainbow trout intestine, as it was demonstrated in seabass larvae (Tovar-Ramírez, Zambonino Infante, Cahu, Gatesoupe \&. Vazquez-Juárez 2004).

The experimental treatments affected the intestinal microbiota. Ten days after stopping the antibiotic treatment, the bacterial counts were highly variable, indicating that the disturbance was not recovered yet, as already observed by Austin \& Al-Zahrani (1988). By this date, the antibiotic and the two probiotics seemed to stimulate the dominance of Pseudomonas sp. This genus is generally not dominant in trout intestinal microbiota (Spanggaard, Huber, Nielsen, Nielsen, Appel \& Gram 2000; Huber, Spanggaard, Appel, Rossen, Nielsen \& Gram 2004). However, Ringø (1993) identified up to $37.9 \%$ of the isolates from Arctic charr faeces as Pseudomonas spp. Some Pseudomonas isolates from rainbow trout have been reported to be antagonistic to fish pathogens (Sugita, Shibuya, Shimooka \& Deguchi 1996; Spanggaard, Huber, Nielsen, Sick, Pipper, Martinussen, Slierendrecht \& Gram 2001). It was therefore possible that the dominant strain of Pseudomonas sp. had some effect on the putative pathogen, though the probiotic yeast and the short-term treatment with $P$. acidilactici were not efficient against VCCS. After 5 months Carnobacterium sp. was the dominant strain, even in the control group. Such a dominance has been already observed in salmonids (Gonzalez, Lopez-Diaz, Garcia-Lopez, Prieto \& Otero 1999; Ringø, Bendiksen, Wesmajervi, Olsen, Jansen \& Mikkelsen 2000), and some strains may have antagonistic properties (Joborn, Olsson, Westerdahl, Conway \& Kjelleberg 1997; Ringø et al. 2000; Ringø, Seppola, Berg, Olsen, Schillinger \& Holzapfel 2002). They may also stimulate the immune system (Irianto \& Austin 2002; 2003). It should be kept in mind that autochthonous microbes may interfere with the effect of probiotics the host, even when the effect of probiotics on intestinal microbiota is not patent. Consequently, the effects of $P$. acidilactici and $S$. cerevisiae should be further tested in rainbow trout with other environmental conditions, where the dominant microbes may be different.

\section{Conclusion}

The aetiology of VCCS has not been defined yet, but the efficiency of the antibiotic supports the hypothesis of the involvement of pathogenic bacteria.

Our results showed that it was possible to obtain a significant limitation of VCCS in rainbow trout at the fry stage by supplementing food with $P$. acidilactici. After 5 months of continuous treatment, the level of protection seemed similar to that obtained with the preventive antibiotic treatment, but the probiotic was not efficient when it was applied only for the first 20 days of feeding. The minimum duration of this treatment should be further investigated. The way of action of the probiotic needs to be clarified. We hypothesised that it could be either direct, due to bacteriostatic properties, or indirect, by stimulating favourable intestinal microbiota. However it may be different from the way of action of the antibiotic. The probiotic treatment would be advisable as a harmless alternative to antibiotics, due to the lack of risk of toxicity 
and antibio-resistance spread. Nevertheless it is essential to repeat these results to validate the efficiency of a $P$. acidilactici supplementation, before considering its practical application. This will require a large-scale investigation in several farms representative of diverse breeding conditions and microbial environments.

\section{Acknowledgements}

This study was partly supported by Lallemand Animal Nutrition S.A. (Blagnac, France), who collaborated with Biomar S.A. (Nersac, France) to adjust the incorporation process of the probiotics into the diets, kindly prepared for the experiment.

\section{References}

Andlid T., Juárez R.V. \& Gustafsson L. (1995) Yeast colonizing the intestine of rainbow trout (Salmo gairdneri) and turbot (Scophthalmus maximus). Microbial Ecology 30, 321-334.

Austin B. \& Al-Zahrani M.J. (1988) The effect of antimicrobial compounds on the gastrointestinal microflora of rainbow trout, Salmo gairdneri Richardson. Journal of Fish Biology 33, 1-14.

Bhunia A.K., Johnson M.C., Ray B. \& Belden E.L. (1990) Antigenic property of pediocin AcH produced by Pediococcus acidilactici H. Journal of Applied Bacteriology 69, 211-215.

Ceremonie H., Buret F., Simonet P. \& Vogel T.M. (2004) Isolation of lightning-competent soil bacteria. Applied Environmental Microbiology 70, 6342-6346.

Charles D.G. \& Fisk D.M. (1966) Vertebral abnormalities in Sockeye, Pink and Chum salmon. Transactions of the American Fisheries Society 95, 177-182.

Duncan P.L. \& Klesius P.H. (1996) Dietary immunostimulants enhance nonspecific immune responses in channel catfish but not resistance to Edwardsiella ictaluri. Journal of Aquatic Animal Health 8, 241-248.

Esteban M.A., Rodriguez A. \& Meseguer J. (2004) Glucan receptor but not mannose receptor is involved in the phagocytosis of Saccharomyces cerevisiae by seabream (Sparus aurata L.) blood leucocytes. Fish \& Shellfish Immunology 16, 447-451.

Felsenstein J. (1996) Inferring phylogenies from protein sequences by parsimony, distance, and likelihood methods. In: Doolittle R.F. (ed.) Computer Methods for Macromolecular Sequence Analysis. Methods in Enzymology 266, 418-427. Academic Press, Orlando, FL.

Gatesoupe F.J. (2002) Probiotic and formaldehyde treatments of Artemia nauplii as food for larval pollack Pollachius pollachius. Aquaculture 212, 347-360.

Gjerde B., Pante J.R. \& Baeverfjord G. (2000) Genetic variation for a spinal deformity in Atlantic salmon. In: VII ${ }^{\text {th }}$ International Symposium Genetic in Aquaculture, 16-22 July, 2000, Townsville, Australia, Book of abstracts, p. 43. 
Gonzalez C.J., Lopez-Diaz T.M., Garcia-Lopez M.L., Prieto M. \& Otero A. (1999) Bacterial microflora of wild brown trout (Salmo trutta), wild pike (Esox lucius), and aquacultured rainbow trout (Oncorhynchus mykiss). Journal of Food Protection 62, 1270-1277.

Groff J.M. \& LaPatra S.E. (2000) Infectious Diseases Impacting the Commercial Culture of Salmonids. Journal of Applied Aquaculture 10, 17-90.

Huber I., Spanggaard B., Appel K.F., Rossen L., Nielsen T. \& Gram L. (2004) Phylogenetic analysis and in situ identification of the intestinal microbial community of rainbow trout (Oncorhynchus mykiss, Walbaum). Journal of Applied Microbiology 96, 117-132.

Hoffman C.S. \& Winston F. (1987) A ten-minute DNA preparation from yeast efficiently releases autonomous plasmids for transformation of Escherichia coli. Gene 57, 267-272.

Irianto A. \& Austin B. (2002) Use of probiotics to control furunculosis in rainbow trout, Oncorhynchus mykiss (Walbaum). Journal of Fish Diseases 25, 333-342.

Irianto A. \& Austin B. (2003) Use of dead probiotic cells to control furunculosis in rainbow trout, Oncorhynchus mykiss (Walbaum). Journal of Fish Diseases 26, 59-62.

Joborn A., Olsson J.C., Westerdahl A., Conway P.L. \& Kjelleberg S. (1997) Colonization in the fish intestinal tract and production of inhibitory substances in intestinal mucus and faecal extracts by Carnobacterium sp. strain K1. Journal of Fish Diseases 20, 383-392.

Kacem A., Meunier F.J., Aubin J. \& Haffray P. (2004) Caractérisation histo-morphologique des malformations du squelette vertébral chez la truite arc-en-ciel (Oncorhynchus mykiss) après différents traitements de triploïdisation. Cybium 28, S15-S23.

Kvellestad A., Hoie S., Thorud K., Thorud B. \& Lyngoy A. (2000). Platyspondyly and shortness of vertebral column in farmed Atlantic salmon Salmo salar in Norway - description and interpretation of pathologic changes. Diseases of Aquatic Organisms 39, 97-108.

Lésel R., Fauconneau B. \& Alzieu P. (1986) Transit bactérien dans le tube digestif de la truite arc-en-ciel. In : GERBAM - Deuxième Colloque International de Bactériologie marine CNRS, Brest, 1-5 Oct. 1984. IFREMER, Actes de Colloques 3, 459-466. IFREMER, Paris.

Madsen L., Arnbjerg J. \& Dalsgaard I. (2000) Spinal deformities in triploid all-female rainbow trout (Oncorhynchus mykiss). Bulletin of the European Association of Fish Pathologists 20, 206-208.

Madsen L., Arnbjerg J. \& Dalsgaard I. (2001) Radiological examination of the spinal column in farmed rainbow trout Oncorhynchus mykiss (walbaum): experiments with Flavobacterium psychrophilum and oxytetracycline. Aquaculture Research 32, 235-241.

Madsen L., I. Dalsgaard, 1999. Vertebral column deformities in farmed rainbow trout (Oncorhynchus mykiss), Aquaculture 171, 41-48.

Margolis M.L., Kent M.L.\& Bustos P. (1996) Diseases of salmonids resembling myxosporean whirling disease, and the absence of Myxosoma cerebralis, in South America. Diseases of Aquatic Organisms 25, 33-37. 
Miranda C.D. \& Zemelman R. (2002) Antimicrobial multiresistance in bacteriça isolated from freshwater Chilean salmon farms. The Science of the Total Environment 293, 207-218.

Mora D., Parini C., Fortina M.G. \& Manachini P.L. (2002) Multilocus hybridization typing in Pediococcus acidilactici strains. Current Microbiology 44, 77-80.

Nikoskelainen S., Ouwehand A., Bylund G., Salminen S. \& Lilius E.M. (2003) Immune enhancement in rainbow trout (Oncorhynchus mykiss) by potential probiotic bacteria (Lactobacillus rhamnosus). Fish \& Shellfish Immunology 15, 443-452.

Ortuño J., Cuesta A., Rodriguez A., Esteban M.A. \& Meseguer J. (2002) Oral administration of yeast, Saccharomyces cerevisiae, enhances the cellular innate immune response of gilthead seabream (Sparus aurata L.). Veterinary Immunology and Immunopathology 85, 41-50.

Petersen K.M., Moller P.L. \& Jespersen L. (2001) DNA typing methods for differentiation of Debaryomyces hansenii strains and other yeasts related to surface ripened cheeses.

International Journal of Food Microbiology 69, 11-24.

Poppe, T.T. (2000) :Husbandry diseases in fish farming - an ethical challenge to the veterinary profession. Norsk Veterinaer Tidsskrift 112, 91-96.

Poynton S.L. (1987) Vertebral column abnormalities in brown trout, Salmo trutta L. Journal of Fish Diseases 10, 53-57.

Ramzu M. \& Meunier F.J. (1999) Descripteurs morphologiques de la zonation de la colone vertébrale chez la truite arc-en-ciel Oncorhynchus mykiss (Walbaum, 1792). Annales des Sciences Naturelles 3, 87-97.

Ringø E. (1993) Does chromic oxide $\left(\mathrm{Cr}_{2} \mathrm{O}_{3}\right)$ affect faecal lipid and intestinal bacterial flora in Arctic charr, Salvelinus alpinus (L.)? Aquaculture and Fisheries Management 24, 767-776.

Ringø E., Bendiksen H.R., Wesmajervi M.S., Olsen R.E., Jansen P.A. \& Mikkelsen H. (2000) Lactic acid bacteria associated with the digestive tract of Atlantic salmon (Salmo salar L.). Journal of Applied Microbiology 89, 317-322.

Ringø E., Seppola M., Berg A., Olsen R.E., Schillinger U. \& Holzapfel W. (2002) Characterization of Carnobacterium divergens strain 6251 isolated from intestine of Arctic Charr (Salvelinus alpinus L.). Systematic and Applied Microbiology 25, 120-129.

Ringø E., Strøm E. \& Tabachek J.A. (1995) Intestinal microflora of salmonids: a review. Aquaculture Research 26, 773-789.

Rudi K., Maugesten T., Hannevik S.E. \& Nissen H. (2004) Explorative multivariate analyses of 16s rRNA gene data from microbial communities in modified-atmosphere-packed salmon and coalfish. Applied Environmental Microbiology 70, 5010-5018.

Ruimy R., Breittmayer V., Elbaze P., Lafay B., Boussemart O., Gauthier M. \& Christen R. (1994) Phylogenetic analysis and assessment of the genera Vibrio, Photobacterium, 
Aeromonas, and Plesiomonas deduced from small-subunit rRNA sequences. International Journal of Systematic Bacteriology 44, 416-426.

Saldler J., Pankhurst P.M. \& King H.R. (2001) High prevalence of skeletal deformity and reduced gill surface area in triploid Atlantic salmon (Salmo salar L.). Aquaculture 198, 369386.

Schapiro H.C., Mathewson J.H., Steenbergen J.F., Kellogg S., Ingram C., Nierengarten G. \& Rabin H. (1974) Gaffkemia in the California spiny lobster, Panulirus interruptus: Infection and immunization. Aquaculture 3, 403-408.

Siwicki A.K., Anderson D.P. \& Rumsey G.L. (1994) Dietary intake of immunostimulants by rainbow trout affects non-specific immunity and protection against furunculosis. Veterinary Immunology and Immunopathology 41, 125-139.

Spanggaard B., Huber I., Nielsen J., Nielsen T., Appel K.F. \& Gram L. (2000) The microflora of rainbow trout intestine: a comparision of traditional and molecular identification.

Aquaculture 182, 1-15.

Spanggaard B., Huber I., Nielsen J., Sick E.B., .Pipper C.B., Martinussen T., Slierendrecht W.J. \& Gram L. (2001) The probiotic potential against vibriosis of the indigenous microflora of rainbow trout. Environmental Microbiology 3, 755-765.

Sugita H., Shibuya K., Shimooka H. \& Deguchi Y. (1996) Antibacterial abilities of intestinal bacteria in freshwater cultured fish. Aquaculture 145 195-203.

Suzuki Y. (2001) Some aspects of larval immunity. In: Hendry C.I., Van Stappen G., Wille M. \& Sorgeloos P. (eds.), Larvi'01 - Fish \& Shellfish Larviculture Symposium, European Aquaculture Society, Special publication N³0, Oostende, Belgium, pp. 611-613.

Toften H., Jobling M. (1996) Development of spinal deformities in Atlantic salmon and Arctic charr fed diets supplemented with oxytetracycline. Journal of Fish Biology 49, 668677.

Tovar-Ramírez D., Zambonino Infante J., Cahu C., Gatesoupe F.J. \&. Vazquez-Juárez R. (2004) Influence of dietary live yeast on European sea bass (Dicentrarchus labrax) larval development. Aquaculture 234, 415-427.

Vagsholm I. \& Djupvik O. (1998) Risk factor for spinal deformities in Atlantic salmon, Salmo salar L. Journal of Fish Diseases 21, 47-53.

Villamil L., Tafalla C., Figueras A. \& Novoa B. (2002) Evaluation of immunomodulatory effects of lactic acid bacteria in turbot (Scophthalmus maximus). Clinical and Diagnostic Laboratory Immunology 9, 1318-1323.

Yoshimizu M., Kimura T. \& Sakai M. (1976) Studies on the intestinal microflora of salmonids $-\mathrm{V}$. The intestinal microflora of the anadromous salmon. Bulletin of the Japanese Society of Scientific Fisheries 42, 1291-1298. 
Table 1: Means ( \pm s.e.) of fork length $(\mathrm{cm})$, wet weight $(\mathrm{g})$ and cumulative mortality $(\%)$ of the experimental groups at the end of the experiment. Means with the same superscript were not significantly different

\begin{tabular}{lcccccc}
\hline & $\mathrm{C}$ & $\mathrm{A}$ & $\mathrm{L} 1$ & L5 & B1 & B5 \\
\hline Fork length $(\mathrm{cm})$ & $9.9^{\mathrm{a}} \pm 0.2$ & $10.3^{\mathrm{a}} \pm 0.1$ & $10.2^{\mathrm{a}} \pm 0.1$ & $9.8^{\mathrm{a}} \pm 0.2$ & $9.8^{\mathrm{a}} \pm 0.2$ & $9.8^{\mathrm{a}} \pm 0.2$ \\
\hline Wet weight $(\mathrm{g})$ & $13.1^{\mathrm{a}} \pm 0.6$ & $13.8^{\mathrm{a}} \pm 0.5$ & $13.7^{\mathrm{a}} \pm 0.6$ & $12.6^{\mathrm{a}} \pm 0.6$ & $12.3^{\mathrm{a}} \pm 0.6$ & $12.3^{\mathrm{a}} \pm 0.6$ \\
\hline Mortality $(\%)$ & $9.9^{\mathrm{a}} \pm 0.5$ & $19.3^{\mathrm{b}} \pm 2.3$ & $7.2^{\mathrm{a}} \pm 0.9$ & $9.2^{\mathrm{a}} \pm 0.7$ & $8.6^{\mathrm{a}} \pm 1.2$ & $9.7^{\mathrm{a}} \pm 1.2$ \\
\hline
\end{tabular}

Table 2: Breakdown of the average numbers and percentages ( \pm s.e.) of abnormal vertebrae per fish affected by the vertebral column compression syndrome according to anatomical regions. Percentages with different superscripts were significantly different

\begin{tabular}{|c|c|c|c|c|c|}
\hline Region & cranial & $\begin{array}{l}\text { Trunco- } \\
\text { cranial }\end{array}$ & $\begin{array}{c}\text { Trunco- } \\
\text { caudal }\end{array}$ & caudal & All regions \\
\hline $\begin{array}{c}\text { Average number of } \\
\text { vertebrae* }\end{array}$ & 8 & 22 & 21 & 9 & 60 \\
\hline $\begin{array}{l}\text { Average number of } \\
\text { abnormal vertebrae }\end{array}$ & 0 & $\begin{array}{r}1.06 \\
\pm 0.30 \\
\end{array}$ & $\begin{array}{r}7.90 \\
\pm 0.78 \\
\end{array}$ & $\begin{array}{r}1.22 \\
\pm 0.24 \\
\end{array}$ & $\begin{array}{r}10.18 \\
\pm 1.01 \\
\end{array}$ \\
\hline $\begin{array}{l}\text { Average percentage } \\
\text { of abnormal vertebrae }\end{array}$ & 0 & $\begin{array}{l}4.84^{\mathrm{c}} \\
\pm 1.38\end{array}$ & $\begin{array}{l}37.6^{\mathrm{a}} \\
\pm 3.71\end{array}$ & $\begin{array}{l}13.56^{\mathrm{b}} \\
\pm 2.68\end{array}$ & $\begin{array}{l}16.97 \\
\pm 1.68\end{array}$ \\
\hline
\end{tabular}


Table 3: Microbial counts in the intestine of trout at 20 day post start feeding, after $20 \mathrm{~h}$ starvation, in $\log \left(\mathrm{CFU} \mathrm{g}^{-1}\right)$; Means $\left( \pm\right.$ s.e. $\left.;^{\varepsilon} \mathrm{n}=3 ;{ }^{\S} \mathrm{n}=6\right)$ with the same superscript within the same row were not significantly different; nd: not detected. Groups L and B gather groups L1 and $\mathrm{L} 5, \mathrm{~B} 1$ and $\mathrm{B} 5$, respectively.

\begin{tabular}{lcccc}
\hline & $\mathrm{C}^{£}$ & $\mathrm{~A}^{£}$ & $\mathrm{~L}^{\S}$ & $\mathrm{B}^{\S}$ \\
\hline Autochthonous Bacteria & $5.8^{\mathrm{a}} \pm 0.7$ & $6.2^{\mathrm{a}} \pm 1.2$ & $5.2^{\mathrm{a}} \pm 0.3$ & $5.4^{\mathrm{a}} \pm 0.5$ \\
Autochthonous Yeast & $4.0^{\mathrm{a}} \pm 0.3$ & $5.3^{\mathrm{a}} \pm 0.2$ & $3.3^{\mathrm{a}} \pm 1.1$ & $4.8^{\mathrm{a}} \pm 0.4$ \\
Probiotic strains & nd & nd & $4.5^{\mathrm{b}} \pm 0.3$ & $2.5^{\mathrm{a}} \pm 0.6$ \\
\hline
\end{tabular}


Table 4: Composition (\%) of the bacterial population associated with trout intestine at 20 day post start feeding, after $20 \mathrm{~h}$ starvation. Groups L and B gather groups L1 and L5, B1 and B5, respectively.

\begin{tabular}{|c|c|c|c|c|}
\hline & $\mathrm{C}$ & A & $\mathrm{L}$ & $\mathrm{B}$ \\
\hline Pseudomonas sp. PL3A0 $0^{\S}$ & 19 & 62 & 58 & 54 \\
\hline \multicolumn{5}{|l|}{ Enterobacteriaceae: } \\
\hline Ewingella americana $\mathrm{PL} \mathrm{A} 3^{\$}$ & 12 & nd & 8 & 8 \\
\hline Enterobacter sp. EB223 $3^{\S}$ & 8 & 4 & nd & nd \\
\hline Buttiauxella sp. & 4 & nd & nd & nd \\
\hline Citrobacter sp. & 4 & nd & nd & nd \\
\hline Serratia $\mathrm{sp}$. & nd & nd & nd & 8 \\
\hline Others & 15 & 12 & 4 & 12 \\
\hline Aeromonas sp. PT331 $1^{£}$ & 8 & 8 & 4 & 4 \\
\hline Arthrobacter sp. PM3B2 ${ }^{@}$ & nd & nd & 8 & 4 \\
\hline Carnobacterium sp. РT220 & nd & nd & nd & 4 \\
\hline Others & 30 & 14 & 18 & 6 \\
\hline
\end{tabular}

The identification was based on alignment with nucleotide sequences currently available in NCBI database; accession number: ${ }^{\S}$ AJ849474, sequence deposited for this study; accession numbers of homologous fragments: ${ }^{\S} \mathrm{AY} 625608,{ }^{\$} \mathrm{AY} 581130,{ }^{\text {E}} \mathrm{X} 74683,{ }^{\#} \mathrm{AY} 543018$, positions of the first and the last nucleotides corresponding to the fragment in the referenced sequences: 1414-606, 67-920,91-556, 1368-681, respectively; nd: not detected 
Table 5: Microbial counts in the intestine of trout at 5 month post start feeding, after $20 \mathrm{~h}$ starvation, in $\log \left(\mathrm{CFU} \mathrm{g}{ }^{-1}\right)$; Means $( \pm$ s.e. $; n=6)$ with the same superscript within the same row were not significantly different; nd: not detected

\begin{tabular}{lccc}
\hline & $\mathrm{C}$ & L5 & B5 \\
\hline Autochthonous Bacteria & $6.8^{\mathrm{b}} \pm 0.3$ & $5.3^{\mathrm{ab}} \pm 0.6$ & $4.3^{\mathrm{a}} \pm 0.5$ \\
Autochthonous Yeast & nd & $1.9^{\mathrm{a}} \pm 0.9$ & $0.6^{\mathrm{a}} \pm 0.6$ \\
Probiotic strains & nd & nd & $0.9 \pm 0.6$ \\
\hline
\end{tabular}

Table 6: Composition (\%) of the bacterial population associated with trout intestine at 5 month post start feeding, after $20 \mathrm{~h}$ starvation

\begin{tabular}{lccc}
\hline & C & L5 & B5 \\
\hline $\begin{array}{l}\text { Carnobacterium sp. PT220 } \\
\text { Enterobacteriaceae: }\end{array}$ & 73 & 90 & 61 \\
$\quad$ Enterobacter sp. EB223 & nd & nd & \\
$\quad$ Serratia sp. & 7 & nd & nd \\
Aeromonas sp. PT331 & 20 & nd & 13 \\
Others & nd & 10 & 3 \\
\hline
\end{tabular}

The identification was based on alignment with nucleotide sequences currently available in NCBI database; accession number: ${ }^{\S} \mathrm{AJ} 849474$, sequence deposited for this study; accession numbers of homologous fragments: ${ }^{\text {E}} \mathrm{X} 74683,{ }^{\#} \mathrm{AY} 543018$, positions of the first and the last nucleotides corresponding to the fragment in the referenced sequences: 91-556, 1368-681, respectively; nd: not detected 


\section{FIGURES CAPTIONS}

Figure 1: Mean frequency (\%) of malformed fish in the experimental groups. The vertical lines above the histogram correspond to the standard errors. The frequencies with at least one similar letter printed above the bars were not significantly different.

Figure2: X-ray of $12 \mathrm{~g}$ rainbow trout suffering from VCCS in trunco-caudal region of the spinal axis. 


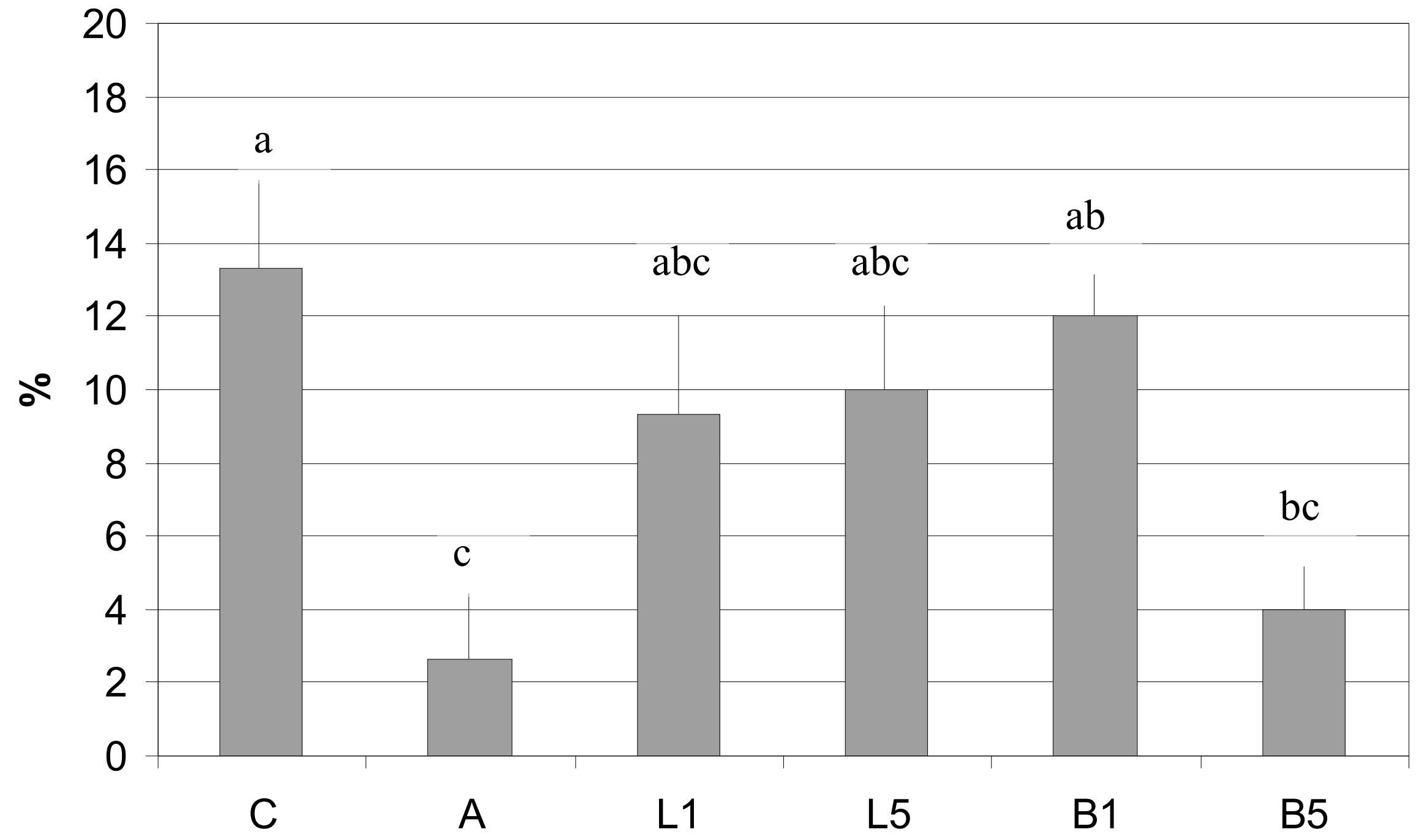




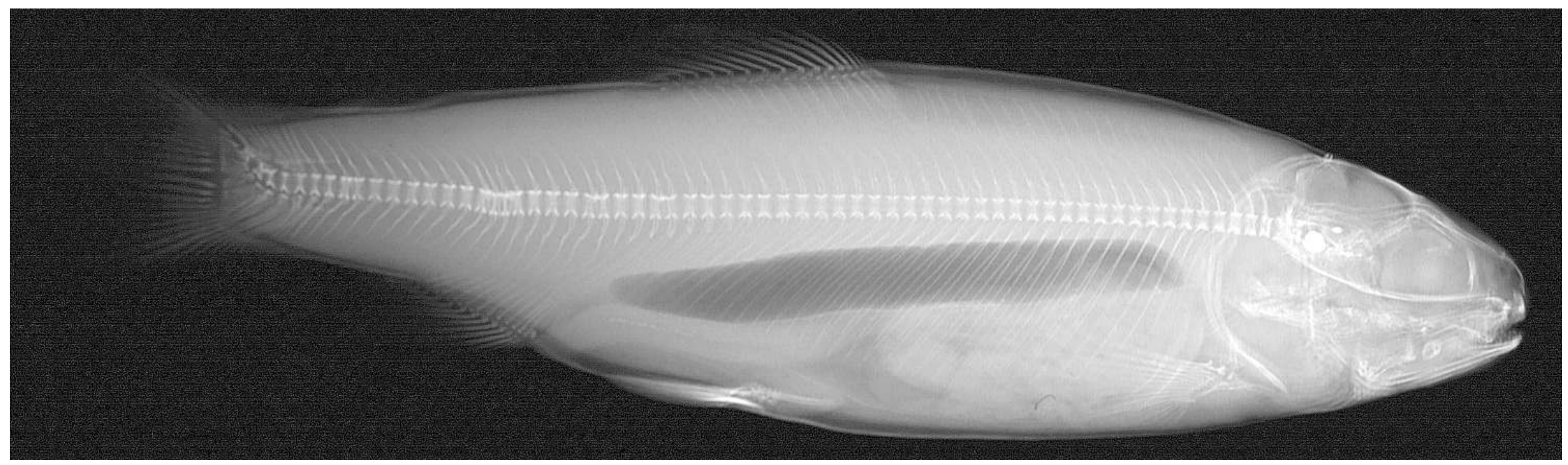

